ORCID: 0000-0002-7384-5675

belichenko@num.kharkiv.ua

\title{
ТРАКТАТ «ПРАВИЛА ГАРМОНІЧНІ Й МЕЛОДИЧНІ...» В. МАНФРЕДІНІ У ПЕРЕКЛАДІ С. ДЕГТЯРЬОВА В ПАРАДИГМІ СУЧАСНОї ТЕОРІї ПОЛІФОНІї
}

\begin{abstract}
Мета роботи. Розглянуто місце в парадигмі сучасної вітчизняної теорії поліфонії трактату В. Манфредіні "Regole armoniche, o sieno precetti ragionevoli per apprendere la musica" (“Гармонічні правила, або розумні настанови для навчання музиці”, 1797 р., Венеція) у творчому перекладі видатного українського композитора С. Дегтярьова («Правила гармонічні та мелодичні для навчання усій музиці», 1805 р., Санкт-Петербург). Методологія роботи поєднує історико-культурологічний, системноструктурний і теоретичний підходи, що дозволило виявити ключову роль розглядуваної перекладацької праці С. Дегтярьова, поперше, у виході із назрілої на той момент кризової ситуації у вітчизняній музичній педагогіці, по-друге, - у подальшому після «Музикальної граматики» М. Дилецького процесі поступової європеїзації теоретичної музичної освіти та, ширше, секуляризації музичного мистецтва на теренах України та Росії у відповідності до загальних соціокультурних реалій. Наукова новизна полягає у приверненні спеціальної уваги до перекладеної С. Дегтярьовим праці В. Манфредіні як відправної точки для сучасної вітчизняної теорії музики і зокрема теорії поліфонії. Висновки. Встановлено, що поява на порубіжжі XVIII-XIX ст. перекладацької праці С. Дегтярьова забезпечила сприятливі умови для трансмісії нової - західноєвропейської - культурної парадигми в музичному мистецтві, протягом декількох десятиліть надалі заповнюючи собою існуючу суттєву прогалину в тогочасній музичнотеоретичній літературі. Виявлено, що роль у цьому процесі творчо здійсненого С. Дегтярьовим перекладу може бути охарактеризована як свідома трансляція на вітчизняному ґрунті європейського музично-теоретичного лексикону Нового часу, зокрема 3 контрапункту і фуги, у вигляді систематично викладеного засадничого кодексу правил.
\end{abstract}

Ключові слова: трактат В. Манфредіні «Правила гармонічні й мелодичні», С. Дегтярьов як перекладач, поліфонічне мислення, теорія поліфонії, контрапункт, фуга.

Беличенко Наталия Николаевна, кандидат искусствоведения, доцент, доцент и докторант кафедры теории музыки Харьковского национального университета искусств имени И. П. Котляревского

Трактат «Правила гармонические и мелодические...» В. Манфредини в переводе С. Дегтярева в парадигме современной теории полифонии

Цель работы. Рассмотрено место в парадигме современной теории полифонии трактата В. Манфредини «Regole armoniche, o sieno precetti ragionevoli per apprendere la musica» («Гармонические правила, или разумные предписания для обучения музыке», 1797 г., Венеция) в творческом переводе выдающегося украинского композитора С. Дегтярева («Правила гармонические и мелодические для обучения всей музыке», 1805 г., Санкт-Петербург). Методология работы сочетает историкокультурологический, системно-структурный и теоретический подходы, что позволило выявить ключевую роль рассматриваемой переводческой работы С. Дегтярева, во-первых, в выходе из назревшей к тому моменту кризисной ситуации в отечественной музыкальной педагогике, во-вторых, - в дальнейшем после «Музыкальной грамматики» Н. Дилецкого процессе постепенной европеизации теоретического музыкального образования и, шире, секуляризации музыкального искусства на территории Украины и России в соответствии с общими социокультурными реалиями. Научная новизна заключается в привлечении специального внимания к переведенному С. Дегтяревым труду В. Манфредини как отправной точке для современной отечественной теории музыки и в частности теории полифонии. Выводы. Установлено, что появление на рубеже XVIII-XIX вв. переводческой работы С. Дегтярева обеспечило благоприятные условия для трансмиссии новой - западноевропейской - культурной парадигмы в музыкальном искусстве, в течение нескольких десятилетий в дальнейшем заполняя собой значительный пробел, существующий в музыкально-теоретической литературе того времени. Выявлено, что роль в данном процессе творчески осуществленного С. Дегтяревым перевода может быть охарактеризована как сознательная трансляция на отечественной почве европейского музыкально-теоретического лексикона Нового времени, в частности в сфере контрапункта и фуги, в виде систематически изложенного базового кодекса правил.

Ключевые слова: С. Дегтяев как переводчик, трактат В. Манфредини «Правила гармонические и мелодические», полифоническое мышление, теория полифонии, контрапункт, фуга.

Belichenko Nataliya, Ph.D. in Arts, Associate professor, Associate professor and Doctoral candidate of the Department of Music Theory, I. P. Kotlyarevsky Kharkiv National University of Arts

V. Manfredini's treatise "The harmonic and melodic rules" in S. Degtyaryov's translation in the paradigm of the modern theory of polyphony

Purpose of the article. A place in the paradigm of the modern theory of polyphony of the treatise «Regole armoniche, o sieno precetti ragionevoli per apprendere la musica» by V. Manfredini («Harmonic rules, or reasonable precepts for learning of music», 1797, Venice) is considered in the creative translation of an outstanding Ukrainian composer Degtyaryov («Harmonic and Melodic Rules for learning of all music», 1805, St. Petersburg). The methodology of the work combines historical, cultural, system-structural and theoretical approaches, which revealed the key role of the considered translation work of S. Degtyaryov, firstly, in getting out of the crisis situation that had matured by that time in the domestic musical pedagogy, secondly, in the next - after a «Musical Grammar» by M. Diletsky - process of gradual Europeanization of theoretical music education and, more broadly, the secularization of musical art in Ukraine and Russia in accordance with the general socio-cultural realities. Scientific novelty consists in drawing special attention to the work of V. Manfredini, translated by S. Degtyarev, as a starting point for the modern Russian theory of music and, in particular, the theory of polyphony. Conclusions. It is established that the appearance at the turn of the XVIII-XIX centuries the S. Degtyaryov's translation work provided favorable conditions for the transmission of a new - Western European - cultural paradigm in music, for several decades later filling in the existing significant gap in the then musical theoretical literature. It is revealed that the role of the translation work creatively carried out by S. Degtyaryov in this process can be characterized as a conscious translation on the national basis of the European musical-theoretical vocabulary of the New Age, in particular, of counterpoint and fugue, in the form of a systematic set of basic rules.

() Беліченко Н. М., 2019 
Key words: S. Degtyaryov as translator, treatise "Harmonic and Melodic Rules" by V. Manfredini, polyphonic thinking, the theory of polyphony, counterpoint, fugue.

Актуальність теми дослідження. Питання витоків і специфіки формування сучасної вітчизняної музично-теоретичної термінологічної системи, зокрема поліфонічної, неодноразово поставало в центрі уваги науковців. Воно фокусує у собі багатоскладний комплекс споріднених проблем, пов'язаних із процесом поступової європеїзації професійної теоретичної музичної освіти та, ширше, секуляризації музичного мистецтва на теренах України та Росії у відповідності до соціокультурних реалій порубіжжя XVIII-XIX ст. Через призму ґенези музично-теоретичної термінології уможливлюється поглиблене розуміння і переосмислення не тільки початкових етапів становлення музичної науки, освіти, виконавської та композиторської практики, але й специфіки національного поліфонічного мислення, - тому її вивчення, як і раніше, залишається гостроактуальним. Утім, наразі відсутні окремі спеціальні розвідки, присвячені трактату В. Манфредіні «Regole armoniche, o sieno precetti ragionevoli per apprendere la musica» («Гармонічні правила, або розумні настанови для навчання музиці», 1797 р., Венеція) у перекладі видатного українського композитора С. Дегтярьова («Правила гармонічні та мелодичні для навчання усій музиці», 1805 р., Санкт-Петербург) в контексті його ключової ролі у вищезгаданому процесі.

Аналіз досліджень і публікацій. Уперше провідну роль перекладу С. Дегтярьова у введенні в обіг західноєвропейської термінології в галузі поліфонії відзначив Є. Левашев [9, 191]. Побічно порушувалося це питання І. Пресняковою [12]. У переважній більшості робіт трактат В. Манфредіні залучається, в основному, в історичному та теоретичному аспектах вокальної педагогіки, виконавської майстерності або виховання музичного слуху, що не є предметом цього дослідження. До окремої групи джерел слід віднести праці з питань музичної творчості, стилю і особистості С. Дегтярьова (значна частина з них належить сучасним українським науковцям), які в тій чи іншій мірі висвітлюють фракт перекладацької діяльності композитора, загальний зміст і значення російськомовного перекладу праці В. Манфредіні, - зокрема розвідки М. Рицаревої [14], А. Лебедєвої-Ємеліної [8], Ю. Горяйнова [4], Т. Гусарчук [6], Л. Руденко [13] та ін.

Мета дослідження - обґрунтувати місце, яке належить в парадигмі сучасної теорії поліфонії трактату В. Манфредіні «Правила гармонічні та мелодичні...» у перекладі С. Дегтярьова (1805 р.).

Виклад основного матеріалу. Для розуміння актуальності і своєчасності появи російського перекладу музично-теоретичного трактату В. Манфредіні на початку XIX століття, необхідно коротко висвітлити ситуацію, що склалася на той час у вітчизняній професійній музичній педагогіці. Насамперед, слід відмітити, що стан її музично-теоретичних засад на порубіжжі XVIII-XIX ст. зазнає певної кризи, значною мірою не відповідаючи потребам у назрілій новій - західноєвропейській - культурній парадигмі. Універсальна «Музикальна граматика» М. Дилецького (перша редакція - 1675 р., остання - 1723 р.) протягом більше аніж століття перед тим була головною настільною книгою не одного покоління регентів, композиторів, церковних співаків, учнів монастирських і приходських шкіл. Підбиваючи підсумки попереднього етапу становлення національної професійної освіти і практики, ця праця водночас синтезує їх з окремими новітніми елементами тогочасної західноєвропейської музичної теорії. Утім, у другій половині XVIII ст. культурні тенденції, започатковані ще реформами Петра I, набувають все більш стрімкого подальшого поширення. Поступово утворюється розвинена світська музична «інфраструктура» у вигляді мережі освітніх установ та концертних товариств. У якості придворних капельмейстерів і вчителів, крім В. Манфредіні, систематично залучаються найкращі італійські композиторські сили, зірки першої величини, як-от Дж. А. Рісторі, Ф. Арайя, Ф. Цоппіс, Б. Ґалуппі, Т. Траетта, Дж. Паїзієлло, Дж. Сарті, Д. Чімароза та ін., викладачі музики італійського походження отримують пріоритетні позиції у педагогіці й суспільстві. Повсюдно виникають й активно розвиваються аматорські та професійні приватні та публічні хорові та театральні трупи, причому деякі з них не поступаються виконавською майстерністю столичним колективам, маючи в своєму репертуарі надзвичайно складні, різноманітні за жанрами віртуозні твори, зокрема кантатно-ораторіальні та оперні (від seria до buffa). Отже, поступово виникає нагальна потреба у навчальних посібниках інакшого типу, орієнтованих на сучасний музичний (насамперед італійський) стиль. Саме цим і пояснюється, що першими вітчизняними музично-теоретичними підручниками нового - світського, європейського - напряму були переклади італійських та французьких за своїм походженням трактатів, а не німецьких, які з'явилися і набули своєї незаперечної авторитетності значно пізніше, вже у другій половині XIX ст. у безпосередньому зв'язку зі становленням академічної музичної освіти в Росії'.

Серед низки перших перекладів музично-практичних порадників з італійської та французької, крім розглядуваного посібника В. Манфредіні (1805 р.), варто згадати «Музичну граматику» директора міланської консерваторії Б. Азіолі (1826 р.) у російському перекладі Д. Кушенова-Дмитревського [1], а також праці Ф. Фетіса «Музика, зрозуміла для всіх» та «Історичні достопам'ятності музики» (1833 р.) [16; 15]. Хоча з плином часу ці видання, щоправда, поступово набули набагато більшої популярності, аніж переклад трактату В. Манфредіні, необхідно враховувати, що вийшли друком вони значно пізніше за останнього. Окремо слід зазначити неабияку роль двох праць, які було створено вітчизняними митцями. Перша з них - «Досвід вокальної або співацької музики в Росії» М. Горчакова [3], відомого 
літератора, автора лібрето ораторії «Мінін і Пожарський» С. Дегтярьова. Цікаво, що зазначений порадник М. Горчакова вийшов друком у 1808 році, тобто ще за часів життя автора ораторії, перекладача трактату В. Манфредіні. Іншою працею $є$ ґрунтовна «Теорія музики» у двох частинах (у російському перекладі Р. Гонорського), яку було віддруковано у типографії харківського університету у 1818 році [2]. Постать автора книги, Г. Гесс-де-Кальве, - музиканта (піаніста, диригента), мінералога, доктора філософії харківського університету, старшого члена гірничого правління луганського ливарного заводу, - вражає справжнім універсалізмом і енциклопедичністю знань і давно заслуговує на низку відповідних різногалузевих монографічних досліджень.

Отже, окреслена вище ситуація в музично-педагогічній практиці порубіжжя XVIII-XIX cт. свідчить про виключну роль здійсненої у 1805 р. С. Дегтярьовим, видатним українським композитором, досвідченим музикантом, якого сучасники іменували «російським Гайдном», своєчасної трансляції новітнього європейського музично-теоретичного лексикону (у вигляді систематичного викладення засадничого кодексу правил) з метою його вкорінення (трансмісії) на вітчизняному грунті. Про те, що С. Дегтярьов, очевидно, саме так і усвідомлював кінцеву мету своєї роботи, відповідально та вимогливо ставлячись до вибору зарубіжного джерела, засвідчує текст присвяти графу М. П. Шереметьєву, наведений на початку книги: «С некоторого времени упражняясь в приискании на иностранных языках хороших музыкальных правил, по счастливому случаю, теперь нашел несколько соответствующих моему желанию. Сия книга, заключающая таковые правила, была издана на итальянском языке итальянцем г-ном Манфредини в четырех частях и поднесена от него была в 1797 году императору Павлу Первому. ...Ибо хотя и прежде сего были издаваемы правила, но только о генерал-басе ${ }^{2}$, а о сочинении самой музыки никогда еще не были издаваемы на нашем диалекте подобные сим правила» [11, 5-6] (виділене мною - Н. Б.)

Зауважимо, що на той час у вітчизняній музичній педагогіці, на відміну від тогочасної західноєвропейської, не існувало єдиної спільної термінологічної системи, що, звичайно, чинило серйозні перешкоди на шляху створення універсальної музичної теорії. Тому для запобігання плутанини С. Дегтярьов наводить назви усіх розділів, підрозділів, основні визначення, музичні терміни у двох мовних варіантах - російському та оригінальному, італійському. В окремому зверненні до свого читача перекладач більш детально пояснює доцільність наявної у посібнику двомовної термінології і разом з тим окреслює ключові моменти своєї праці: «Благоразумный читатель! Прежде начатия чтения сей книги, долгом поставляю предуведомить тебя о некоторых вещах.

1. Читавши сию книгу найдешь ты много слов итальянских, которые я употреблял не для того, чтобы их не можно было изразить на российском языке, но чтобы учащийся, в случае разговора с иностранцем, мог разуметь как его вопросы, так и отвечать на оные. При том же удержание слов иностранных и для политического разговора о музыке я почел весьма нужным. Впрочем, для именования интервалов и прочих означений присоединены мною в некоторых главах изъяснения.

2. При конце сей книги господин Манфредини присоединил примеры многих писателей музыки как искусных, так и посредственных, которых я не почел за нужное переводить, ибо в оных заключается то, что если кто пожелает следовать наставлениям г-на Манфредини, то конечно будет знать положение музыки правильной и неправильной» [11, 9-10].

Впадають в око принаймні дві обставини. По-перше, вводячи в обіг чималу кількість новостворених російськомовних понять, С. Дегтярьов, як бачимо, водночас дбає про збереження, так би мовити, міжнародної «конвенції» щодо їх розуміння, аргументуючи необхідність двомовної (російськоіталійської) термінології як запоруки взаєморозуміння при спілкуванні із закордонними фахівцями, що, зауважимо, і наразі не втрачає своєї актуальності. По-друге, композитор ставиться до перекладу трактату досить вільно, залишаючи питання відбору, скорочень, коментування авторського тексту, додавання власного тексту тощо на власний розсуд, тобто виконує функцію не тільки перекладача, але й редактора, а подекуди навіть і співавтора.

Виникають резонні питання щодо особистості автора трактату, на якому зупинив свій вибір С. Дегтярьов, а також особливостей оригіналу «Правил». Італійський композитор і теоретик В. Манфредіні (1737-1799), призначений у 20-річному віці капельмейстером придворної співацької капели у Петербурзі, водночас виконував обов'язки вчителя музики майбутнього імператора Павла I. У 1769 році композитор повернувся до Венеції, де згодом написав перший варіант трактату «Regole armoniche: o sieno precetti ragionati per apprender la musica» (вийшов друком у 1775 р.). У 1797 р. вийшло друге видання (там само), значно розширене і змінене. Зокрема, нове видання поповнилося новою (четвертою) частиною, яка містила правила контрапункту та фуги (на цьому, до речі, наголошує сам автор у вступі до посібника $[11,17])$. Присвята Павлові I та переїзд В. Манфредіні в 1799 р. після 30-річної перерви до Петербургу (де йому судилося незабаром відійти у вічність), а також цілком ймовірне особисте спілкування обох митців, - усі ці обставини певною мірою могли вплинути і на вибір трактату для перекладу С. Дегтярьовим. Утім, В. Манфредіні як досвідчений композитор, професійний педагог і теоретик вдало сполучав у собі сучасний європейський академізм із глибоким розумінням засад російської національної хорової культури. Завдяки цим якостям, а також блискучому «співавторству» композитора і капельмейстера С. Дегтярьова, трактат швидко знайшов свого читача і набув неабиякої популярності серед музикантів, належних до різних соціальних верств. 
Порівнюючи «Правила гармонічні і мелодичні» (1805 р.) з «Музикальною граматикою» М. Дилецького (1723 р.), можна повною мірою усвідомити, яка епохальна відстань, незважаючи на лише 82 роки у часі, пролягає між ними, відділяючи собою підготовчий та класичний етапи становлення нової стильової парадигми у вітчизняному професійному музичному мистецтві XVIII ст. Про це красномовно свідчить навіть просте зіставлення перших рядків (присвячених визначенню музики) з обох праць:

«Что єсть музика? Музика то єсть, которая співаннєм албо ли іграннєм своїм сердца людськіє албо до веселости, албо до смутку і жалю побуждаєт. По-вторє что єсть музика? Музика то єсть, которая албо вгору, албо вдолголосом модеруєт» (М. Дилецький) [7, 3].

«Музыка есть искусство составлять из переменных тонов приятную мелодию. Чувствовать оную можно на голосах, с аккомпанированием инструментов, или на инструментах без голосов. Первая называется вокальною, а последняя инструментальною музыкою» (В. Манфредіні) [11, 23].

«Музикальна граматика» написана у формі доброзичливого звернення до зацікавленого читача (композитора, регента, хорового співака), щедро насичена величезною кількістю музичних прикладів, які унаочнюють майже кожну висловлену тезу, демонструє суто практичну спрямованість і більше нагадує методичний порадник для старанного учня аніж академічний словник музичних правил. Натомість трактат В. Манфредіні націлений насамперед на систематичне викладення гармонічних, мелодичних і також контрапунктичних норм сучасної західноєвропейської музики, відповідно до її основних галузей - співу, акомпанементу і композиції. С. Дегтярьов адресує свою працю «розсудливому читачеві» скоріше як узагальнене керівництво до дії, аніж покроковий порадник, чим пояснюється ставлення перекладача до музичних прикладів як до матеріалу другорядного і необов'язкового, що його навіть може бути виключено.

Доречним уявляється коротко перелічити низку російсько- та українськомовних музичнотеоретичних термінів і понять, які уперше отримали близьке сучасному розумінню визначення, набули повсюдного поширення i досі залишаються загальновживаними завдяки саме перекладу С. Дегтярьова, як-от: мелодія, гармонія, голос (партія), ноти, паузи, точки, ключи, інтервали та їх різновиди (великі, малі, зменшені), акорд, арпеджіо («арпеджії»), мажор і мінор, темп, транспозиція, акомпанемент, модуляція, сольфеджіо («сольфеджії»), контрапункт, імітація, канон, фруга тощо. Тож, зважаючи на сказане, важко переоцінити загальний внесок С. Дегтярьова у процес становлення вітчизняної музично-термінологічної системи.

Утім, на найбільш пильну увагу в цьому трактаті заслуговує його остання частина «Правила контрапункту», яка з'явилася лише у другій редакції і в якій уперше у вітчизняній музично-теоретичній літературі викладено теорію контрапункту і фруги у розумінні, що дуже наближується до класичного. Необхідно також враховувати той фракт, що переклад Дегтярьова протягом майже 40 років (принаймні до виходу «Нової методи» Й. Фукса у 1844 р.) залишався практично єдиним російськомовним джерелом систематичного вчення з поліфонії.

Які саме «правила контрапункту», тобто основні засади поліфонічного вчення, наводяться в трактаті? Насамперед варто зазначити, що фундаментом цього вчення свідомо обирається, говорячи сучасною термінологією, вільний стиль поліфонії. Автор трактату критично ставиться до авторитетних на той час ґрунтовних теоретичних праць з контрапункту Дж. Мартіні, Дж. Паолуччі та ін., хоча й вельми майстерних, але малопристосованих до сучасної композиторської практики, яка потребує від подібних видань «открыть легчайший способ обучать музыке» $[11,15]$. Вісім тонів (тобто старовинних церковних ладів) на думку В. Манфредіні $є$ «неправильними», нездатними до вироблення якісної гармонії [11, 134], тому єдино правильними є мажорні та мінорні тони (ладотональності).

Крім того, композитор вважає за доцільне обмежувати кількість хорів, партій, голосів у творі 3 метою уникнення його «неправильності, малозрозумілості та ще меншої приємності» [11, 21]. Зважаючи на те, що в трактаті йдеться про музику, створену для двох хорів, ще більш яснішає його кардинально відмінна позиція від стильових засад «Музикальної граматики», адже для автора останньої як видатного представника епохи українсько-російського бароко - блискуча стретно-поліфонічна техніка двохорного (восьмиголосного) письма була натомість абсолютно нормативною. Саме проти восьмиголосся активно виступає В. Манфредіні, обстоюючи думку, що воно є припустимим виключно як подвоєне чотириголосся і ставлячи за взірець переважно чотириголосні церковні твори Й. Гассе, Л. Лео, Н. Йоммеллі, Б. Ґалуппі, Дж. Перголезі та інших своїх сучасників. Цікаво, що вагомим аргументом на користь переваг «реального» чотириголосся (тобто такого, що містить вельми відмінні між собою партії) для В. Манфредіні є вимога адекватної передачі смислу вербального тексту [11, 112].

Визначення контрапункту в трактаті за допомогою ключового поняття «голосу» (або «партії») вважаємо наближеним до сучасного розуміння поліфонії: «название контрапункто...означает...собрание разных голосов, выдаваемых в одно время чрез партии вокальные или инструментальные, или вместе; и потому разделяется контрапункт на две, на три, на четыре и более партий» [11, 116]. Головна вимога, що висувається до цих («реальних») партій, це їх (реальна) відмінність між собою. Для порівняння, у трактаті М. Дилецького термін «контрапункт» розуміється звужено і за об'ємом фактично збігається зі своїм синкопованим (дисонуючим) різновидом [7, 33]. У зв'язку з наведеним визначенням варто окремо зупинитися також на понятті голосу (або «головній партії»), враховуючи те істотне значення, яке він має як конструктивний елемент виникаючої на його 
основі системної цілісності - контрапункту (поліфонії). Отже, головний голос або партія, за В. Манфредіні, є той (або та), що концертує, тобто «изъясняет и удерживает все мотивы, пассажи и мысли музыкальные» $[11,126]$. Як бачимо, це визначення ґрунтується на функціональному розумінні голосу як носії основного тематизму («музичної думки») твору, на відміну від значно вужчої трактовки «концертування» як типу концертної композиції, пов'язаного з імітаційним розвитком, в трактаті М. Дилецького [7, 33].

Викладення теорії контрапункту В. Манфредіні розгортається за узвичаєним для кожного сучасного студента планом: етимологія і визначення терміну «контрапункт», види голосоведення у двоголоссі («движения» - пряме, побічне і протилежне) і причини заборони паралелізмів досконалих консонансів, простий (нота проти ноти) та «фигуратный» (нота проти 2, 3, 4 нот) контрапункт, імітація, фуга та її основні елементи і різновиди, подвійний, потрійний, четверний контрапункт (тобто так званий складний), канон та його види. Утім, є й відмінності, найсуттєвіша з яких відразу впадає в око, - це строга підпорядкованість результуючої поліфонічної вертикалі гармонії (акордовості) як єдино прийнятна і тому припустима «за промовчанням». Ось, наприклад, який алгоритм зі створення контрапунктичного багатоголосся пропонується в трактаті: «Притом должно его [ученика] предостеречь, чтобы в каждом роде контрапункта прежде всего нашел главный сюжет [тему], потом бы писал бас с цифрами, с означением тонов, и наконец приступал бы писать по положенному басу другие партии, начиная завсегда от наиупотребительнейших» [11, 124]. На перший погляд, перед нами не що інше як план 3 гармонізації мелодії. Утім, як вважає автор трактату, з метою покращення мелодії в будь-якому голосі, $€$ можливим використання також і неповних за своєю будовою акордів, наводячи триголосий приклад із розв'язанням зменшеного тризвуку у неповний тризвук (див. приклад 1, такти 2-3):

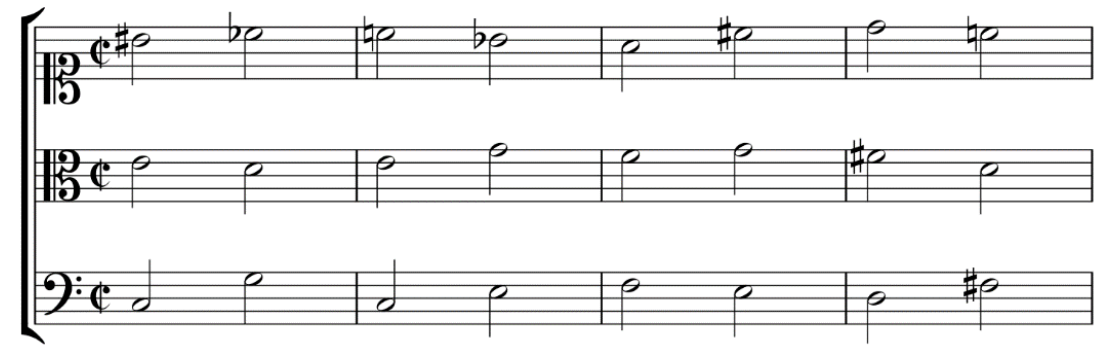

Приклад 1. В. Манфредіні. Regole armoniche (T. XIV. Esem. 3)

У наступному чотириголосному прикладі гармонічна вертикаль $є$ безумовно панівною, хоча й небездоганною, зважаючи на перечення, що утворюється у такті 3 між тенором і сопрано (див. приклад 2, такт 3):

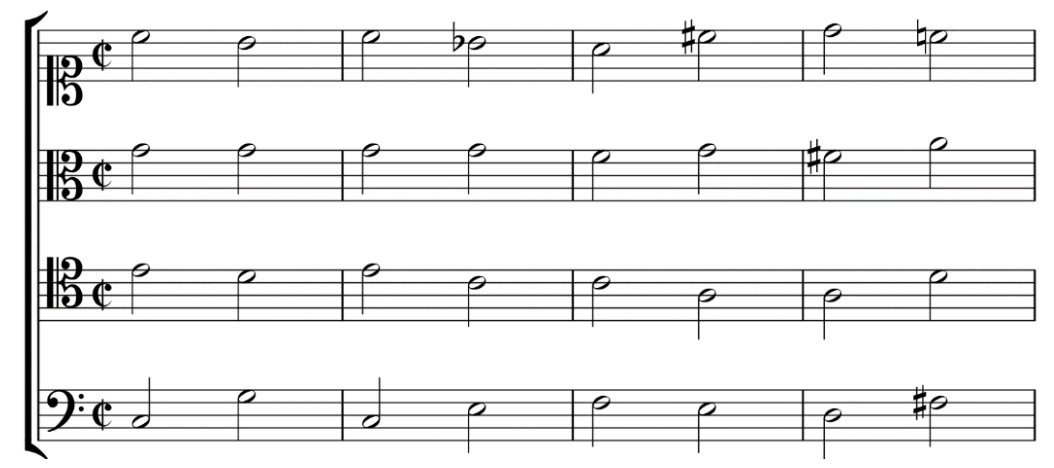

Приклад 2. В. Манфредіні. Regole armoniche (T. XIV. Esem. 4)

Поняття імітації, канону і фуги у трактаті В. Манфредіні наводяться в розумінні, також дуже наближеному до сучасного (вперше у вітчизняній музично-теоретичній літературі). Так, у визначенні імітації пояснюється відмінність імітації від простого повтору, який трапляється у тому самому голосі на тих самих звуках. Тому, пояснює автор, «подражаніє» (або імітація) полягає у тому, щоб утворювати повторення теми («сюжету») в іншому голосі та іншому тоні. Бажаним при цьому є використання пауз перед вступом голосу, який імітує тему $[11,129]$. Описуючи різні за своїми поліфронічними прийомами роди фуг, композитор доходить висновку про те, що імітацію слід визнати засадничою властивістю фуги, «без якої ніяка фуга не була б фугою» [11, 132].

Визначення фуги у розглядуваному трактаті сполучає декілька аспектів, що цілком відповідає її сучасному розумінню. По-перше, жанровий: фуга як вокальний або інструментальний твір в церковній або світській музиці для певної кількості голосів (від двох і більше) [11, 131]. По-друге, тематично- 
композиційний: в основі фуги лежить proposta («сюжет» або мотив), що пропонується однією з партій, далі імітується в другій партії в квінтовому тоні (тональності), внаслідок чого дістало назву risposta, тобто «відповіді». Після цього за тим самим планом має розгортатися повторення у голосах, що залишилися («сюжетів», себто тем, може бути більше ніж один, наприклад, два або три).

Вагоме місце в трактаті В. Манфредіні належить висвітленню контрапунктичного аспекту фуги як «найголовнішої частини контрапункту» [там само]. До двох основних її різновидів композитор зараховує реальну і тонову фуги, тобто такі, які розпочинаються з реальної або тональної відповіді, що безпосередньо випливає з наведених визначень і відповідних детальних нотних прикладів у оригіналі трактату. Заслуговує на особливу увагу поняття «аттаки» («зв'язки»), що фактично є еквівалентом сучасного поняття «кодети», тобто модулюючої одноголосної зв'язки між темою і протискладенням (перед вступом відповіді), котра слугує для знаходження тональності відповіді і саме тому дістала своєї назви, позначаючи зв'язку між двома різними тональностями $[11,135]$.

Викладаючи спосіб написання «приємної» фуги, В. Манфредіні стисло описує усі основні елементи фуги і прийоми перетворення поліфонічної теми, як-от: відповідь, зокрема субдомінантова («от кварты»), протискладення (contra soggetto), контрекспозиція, стретне викладення, прийоми обернення, протируху (інверсії), збільшення («сюжет расширенный»), ракоходу («сюжет наизворот»), відповідь із перетвореннями теми (зокрема інверсією, «ответом противным») тощо.

Окремо стисло розглядається подвійний контрапункт («творець канону», як його іменує В. Манфредіні) у своїх трьох найбільш вживаних різновидах (октави, децими та дуодецими), причому, як бачимо, відразу акцентується зв'язок подвійного контрапункту із канонічною технікою. Канон визначається як «правило», за яким діють усі партії (голоси), що беруть участь в каноні. До його основних характеристик автор зараховує: кількість тем (простий, подвійний, потрійний), замкненість (скінченний або нескінченний), інтервал канону (найбільш приємним для слуху вважається унісон або октава). Отже, в цьому визначенні присутні усі основні загальновідомі характеристики канону.

Підбиваючи підсумки здійсненого огляду, зауважимо, що В. Манфредіні свідомо не прагне до всебічного поглибленого висвітлення поліфонічної техніки, постійно наголошуючи на тому, що поза наполегливою творчою працею над виразністю та приємністю музики, усі розглядувані засоби як такі не мають ніякого сенсу.

Наукова новизна дослідження полягає у приверненні спеціальної уваги до перекладеної С. Дегтярьовим праці В. Манфредіні як відправної точки для сучасної вітчизняної теорії музики і зокрема теорії поліфонії.

Висновки дослідження. Встановлено, що поява на порубіжжі XVIII-XIX ст. перекладацької праці С. Дегтярьова забезпечила сприятливі умови для трансмісії нової - західноєвропейської - культурної парадигми в музичному мистецтві, протягом декількох десятиліть надалі заповнюючи собою існуючу суттєву прогалину в тогочасній музично-теоретичній літературі. Виявлено, що роль творчо здійсненої C. Дегтярьовим перекладацької праці у цьому процесі може бути охарактеризована як свідома своєчасна трансляція основного комплексу європейських академічних музично-теоретичних знань, зокрема з контрапункту і фуги, з метою його поступового вкорінення на ґрунті вітчизняної професесйної музичної освіти.

\section{Примітки}

1 Серед них насамперед слід назвати «Практичний порадник до створення музики» (1830 р.) та «Нову методу» Й. Л. Фукса (1844р.) [17; 18], «Загальний порадник до вивчення музики» В. О. Лемоха (1848 р.) [10], «Повний порадник до створення музики» (1859-1863 рр.) Й. К. Гунке [5].

${ }^{2}$ Очевидно, мається на увазі російський переклад з німецької трактату «Правильна настанова у створенні генерал басу» Д. Кельнера (1791р.)

${ }^{3}$ Йдеться про ґрунтовні примітки, розміщені наприкінці оригіналу трактату В. Манфредіні, а також 20 сторінок із музичними прикладами.

${ }^{4}$ Нотні приклади наводяться за італійським оригіналом трактату В. Манфредіні [19] через їх відсутність у перекладі С. Дегтярьова.

\section{Лimepamypa}

1. Азиоли Б. Музыкальная грамматика, или Теория правил музыки (в вопросах и ответах состоящая). Сочиненная директором и композитором Миланской Королевской Консерватории Б. Азиоли, а переведенная и изданная Д. Дмитриевским. Спб. : в типографии департамента народного просвещения, 1826.90 с.

2. Гесс де Кальве Г. Г. Теория музыки или Разсуждение о сем искустве, заключающее в себе историю, цель, действие музыки, генерал-бас, правила сочинения (композиции), описание инструментов, разные роды музыки и все что относится к ней в подробности; Переведено с немецкой рукописи Разумником Гонорским. Ч. 1, 2. Харьков: в университетской типографии, 1818. 304 с., 389 c.

3. Горчаков Н. Д. Опыт вокальной или певческой музыки в России, от древних времян до нынешняго усовершенствования сего искусства; С любопытными замечаниями об отличных авторах и реэнтах вокальной музыки, и с двумя гравированными фигурами старинных певческих нот. Москва : в губернской типографии у А. Решетникова, 1808.40 с.

4. Горяйнов Ю. С. Степан Аникиевич Дегтяев : К 225-летию со времени рождения. Белгород : Упринформпечать, 1991. $71 \mathrm{c}$

5. Гунке И. К. Полное руководство к сочинению музыки : отд. 1-3. Спб. : у М. Бернарда, б. г. 177 с.

6. Гусарчук Т. В. Хорова творчість Степана Дегтярьова: стильові детермінанти й паралелі Часопис Національної музичної академії України імені П. І. Чайковського. 2013. № 3. С. 117-129.

7. Дилецький М. Граматика музикальна; підгот. О. Цалай-Якименко. Фотокопія рукопису 1723 р. К. : Музична Україна, 1970. ХCIII, 109 с. 
8. Лебедева-Емелина А. В. Хоровая культура России екатерининской эпохи; Гос. ин-т искусствознания. Москва : Композитор, 2010. 303 c.

9. Левашев Е. М. С. А. Дегтярев. История русской музыки : в 10 томах. Т. 4. М. : Музыка, 1986. С. 184-208.

10. Лемох В. О. Общее руководство к изучению музыки, или все, что всякий, игравший на каком-нибудь инструменте, а особенно на фортепианах, должен знать, изданное по Марксу В. О. Лемохом. Москва : в типографии Н. Степанова, 1848.198 с.

11. Манфредини В. Правила гармоническия и мелодическия для обучения всей музыки, Изданныя господином Винченцо Манфредини вторым и помноженным изданием на италиянском языке в 1797 году в Венеции.; С италиянскаго на российский перевел Степан Дехтярев. Санктпетербург: Театральная типография, 1805. 176 с.

12. Преснякова И. А. Становление русскоязычной музыкально-теоретической терминологии в отечественных музыкальных руководствах конца XVIII - первой половины XIX вв. : 1773-1862 : автореферат дис. ... канд. искусствоведения : 17.00.02. Казань, 2004. $21 \mathrm{c}$.

13. Руденко Л. Г. Постать Степана Дегтярьова в історії української музичної культури. Українське музикознавство. 2013. Вип. 39. С. $130-144$.

14. Рыцарева М. Г. Духовный концерт в России второй половины XVIII века. СПб. : Композитор, 2006. 244 с.

15. Фетис Ф. Ж. Исторические достопамятности музыки, необходимо нужное дополнение к книге "Музыка, понятная для всех" ; Соч. Фетиса. изд. журн. "Revue musikal"; Пер. с фр. П. Беликов. Спб : типография Мед. деп. М-ва внутр. дел, 1833. $309 \mathrm{c.}$

16. Фетис Ф. Ж. Музыка, понятная для всех, или краткое изложение всего, чтобы судить и говорить об искусстве сем, не учившись оному ; Соч. Фетиса. изд. журн. "Revue musikale"; Пер. с фpр. [и предисл. снабдил] П. Беликов. Спб : типографрия Мед. деп. М-ва внутр. дел, 1833. 315 с.

17. Фукс И. Л. Практическое руководство к сочинению музыки, в пользу самоучащихся и в облегчение учителей с приложением особенных правил для сочинителей русского церковного пения и двух нотных тетрадей, из которых первая заключает в себе примеры и задачи, а вторая - решение задач, изложенное Л. Фуксом : Пер. с нем. Спб. : типография К. Крайя, 1830. $131 \mathrm{c}$

18. Фукс И. Л. Новая метода, содержащая главные правила музыкальной композиции и руководство к практическому применению их, с кратким изложением оснований двойного контрапункта, канона и фуги, с примерами и упражнениями : Пер. с нем. Г. К. Арнольда. СПб. : Клевер, б.г. 203 с. 1797. $262 \mathrm{p}$.

19. Manfredini V. Regole armoniche: o sieno precetti ragionati per apprender la musica. Venezia : Presso Adolfo Cesare,

\section{References}

1. Azioli, B. (1826). Musical Grammar, or Theory of Music Rules (consisting of questions and answers). Composed by the director and composer of the Milan Royal Conservatory B. Azioli, and translated and published by D. Dmitrievsky. St. Petersburg: in the printing office of the department of public education [in Russian].

2. Hess de Calve, G. G. (1818). Music theory or discourse about this art, which includes the history, purpose, action of the music, general-bass, rules of composition (composition), description of instruments, different kinds of music and everything related to it in detail; Translated from the German manuscript by Razumnik Gonorsky. - Parts. 1, 2. Kharkiv: in university printing office [in Russian].

3. Gorchakov, N. D. (1808). Essay of vocal or singing music in Russia, from the ancient time to the current improvement of this art. With curious remarks about excellent authors and regents of vocal music, and with two engraved figures of old singing notes. Moscow: in the provincial printing house by A. Reshetnikov [in Russian].

4. Gorjajnov, Ju. S. (1991). Stepan Anikievich Degtyarev: To the 225th anniversary of the birth. Belgorod: Uprinformpechat' [in Russian].

5. Gunke, I. K. (without year). The complete guide to composing music: sect. 1-3. St. Petersburg: by M. Bernard [in Russian].

6. Husarchuk, T. V. (2013). Stepan Degtyaryov's choral work: style determinants and parallels. Journal of Tchaikovsky National Music Academy of Ukraine, 3, 117-129 [in Ukrainian].

7. Dylets'kyj, M. (1970). Grammar music; preparations O. Tsalay-Yakimenko. Photocopy of the manuscript of 1723. Kyiv: Musical Ukraine [in Ukrainian].

8. Lebedeva-Emelina, A. V. (2010). Choral culture of Russia in the Catherine era. Moscow: Kompozitor [in Russian].

9. Levashev, E. M. (1986). S. A. Degtyaryev. History of Russian Music: in 10 volumes. T. 4. Moscow: Muzyka [in Russian].

10. Lemoh, V. O. (1848). A general guide to the study of music, or everything that anyone who played on any instrument, and especially on pianos, should know, published according to Marx by V. O. Lemoh. Moscow: in the printing house of N. Stepanov [in Russian].

11. Manfredini, V. (1805). Harmonic and Melodic Rules for learning of all music, published by Mr. Vincenzo Manfredini second and multiplied edition in Italian in 1797 in Venice; From Italian to Russian translated Stepan Dekhtyarev. St. Petersburg: Theater Printing House [in Russian].

12. Presnjakova, I. A. (2004). The formation of Russian-language musical-theoretical terminology in the domestic musical guides of the late XVIII - first half of the XIX centuries. (1773-1862). Extended abstract of Candidate's thesis. Kazan' : Kazan State Conservatoire named after N. Zhiganov [in Russian].

13. Rudenko, L. H. (2013). Stepan Degtyarev figure in the history of Ukrainian musical culture. Ukrains'ke muzykoznavstvo. 39, 130-144 [in Ukrainian].

Russian].

14. Rycareva, M. G. (2006). Spiritual concert in Russia in the second half of the XVIII century. St. Petersburg: Kompozitor [in

15. Fetis, F. Zh. (1833). Historical memorabilia of music, necessary nedeeded addition to the book "Music, understandable for all"; Fetis's writing, published by "Revue Musikal" magazine; Translation from fr. P. Belikov. St. Petersburg: printing house Med. Department of the Ministry of the Interior [in Russian].

16. Fetis, F. Zh. (1833). Music that is comprehensible to all, or a summary of everything to judge and talk about this art without learning it; Fetis's writing, published by the journal. "Revue musikale"; Per. with fr. [and foreword supplied] P. Belikov. St. Petersburg: printing house Med. Department of the Ministry of the Interior [in Russian].

17. Fuks, I. L. (1830). A practical guide to composing music, in favor of self-taught and facilitated teachers with special rules for writers of Russian church singing and two musical notebooks, the first one contains examples and tasks, and the second is problem solving outlined by L. Fuchs: Trans. from German. St. Petersburg: printing house. K. Krajja [in Russian].

18. Fuks, I. L. (without year). The new method, containing the main rules of musical composition and a guide to their practical application, with a brief statement of the bases of double counterpoint, canon, and fugue, with examples and exercises: Trans. With German G. K. Arnold. St. Petersburg: Klever. [in Russian].

19. Manfredini, V. (1797). Regole armoniche: o sieno precetti ragionati per apprender la musica. Venezia : Presso Adolfo Cesare. 